\title{
Wildlife Protection in Mongolia
}

\section{By R. A. Hibbert CMG}

Although the Mongolian People's Republic, last refuge of the Przewalski wild horse, is one of the most thinly populated countries in the world, the wildlife decreased considerably in the 30's and 40's. There has been some improvement in recent years, and the Game Law now gives protection to nearly all mammals - the few exceptions include the wolf, understandably in a country with vast herds of domestic animals. Mr. Hibbert, who was British Chargé d'Affaires at Ulan Bator from 1964 to 1966, and has since spent a year at Leeds University working on Mongolian materials, assesses the status of the major species of mammals, birds and fish, and describes the game laws.

$\mathbf{T}$

HE Mongolian People's Republic is a huge country with a very small population. Its area is just over $1 \frac{1}{2}$ million square kilometres, its population just over $1,100,000$. This gives an average population density of 0.7 per square kilometre or allowing for the concentration of nearly a quarter of the population in the capital at Ulan Bator, a density in rural areas of 0.5 per square kilometre. This seems to be a record low density for a sovereign state. The density of domestic animals-sheep, goats, cows and yaks, horses, camels - is much higher. There are some 24 million domestic animals in the herds, which gives an average density of 15 per square kilometre. Even so, the figures suggest that there is still plenty of room for wild life.

In practice, wild life in the MPR seems to have suffered a serious decline in the past half century, especially in the 30's and 40's, although conservation measures started in the 50's and 60's have begun to remedy the situation. There are several possible reasons for the decline. From 1919 onwards many upheavals and disturbances served to increase the number of modern firearms in use in some form or other in the country. From about 1930 onwards motor vehicles, at first in very small numbers, began to penetrate to the remoter regions. More recently the motorcycle and jeep have appeared. Although the MPR is a mountain country, its rounded, eroded contours and long, sweeping gradients oppose few serious obstacles to motor transport. In the early 30's there was widespread armed rebellion. In 1939 and again in 1945 eastern Mongolia served as the assembly area and starting line for important military operations by joint Soviet-Mongolian forces against the Japanese. Revolution and war tend everywhere to cause scarcities and revive man's passion for and sometimes his dependence on hunting, his earliest means of livelihood. Ever since the MPR was formed in the early 20's, it has been government policy to extend a firm network of settled administration throughout the country and to eliminate the old nomadic way of life. This had the effect of opening up areas which were previously little frequented, but without at first providing a comprehensive system of control. It was not until collectivisation of the herds was completed in 1959, and the collective 


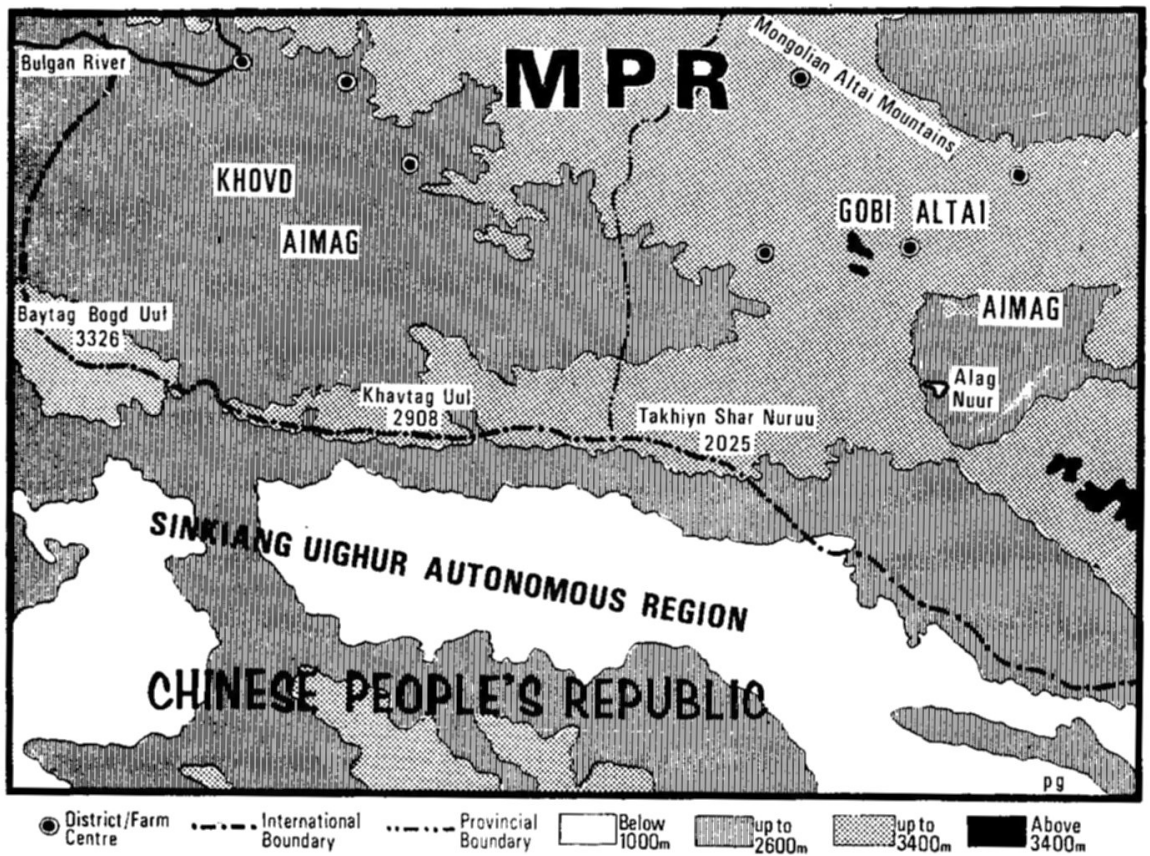

South-West Mongolia and the Chinese frontier, last refuge of the Przewalski wild horse. A map of the whole country is on page 208.

and state farms were thereafter sorted out into some 320 large units coinciding with the somons (districts) of the public administration, that the central authorities acquired the means of controlling, with some degree of finesse throughout the country's vast spaces, such relatively detailed aspects of popular behaviour as hunting. Finally, the furs and skins of wild animals, and in some cases their meat, occupy a small but important place in the list of exports. There has been considerable pressure to maximise exports in order to finance ever-growing requirements of imported goods for consumption and economic development.

A roll-call of the principal wild animals shows what has happened.

\section{MAMMALS}

The rarest wild animal in the MPR is one of the world's rarest mammals, the Przewalski horse. The latest news of it was published in the December 1966 issue of ORYX, where Dr. Kaszab described his sighting of a herd of eight last summer. The accidental sighting and headlong chase after the animals by jeep (probably a Soviet Gazik) are familiar to anyone who has travelled in Mongolia and seen anything from the size of a fox upwards moving in the empty landscape. It is not exactly a scientific procedure, and if repeated too often would extinguish rather than conserve the remaining horses. But, for the moment, there seems little possibility of more refined methods of approach. Dr. Kaszab's report did not bring out clearly the essential point that the mountain ridge which serves as the 
Przewalski horse's last retreat is right on the frontier of the Chinese People's Republic, as the accompanying map shows. The frontier dividing the Mongolian provinces of Gobi Altay and Khovd from the SinkiangUighur Autonomous Region of the CPR runs along the crests of Baytag Bogd Uul, Khavtag Uul and Takhiyn Shar Nuruu. The Dzhungarian Gobi, in which Dr. Kaszab says that the horse may continue to survive, is in Sinkiang, and the horses which Dr. Kaszab saw may well have galloped away into China. It is unlikely that anything short of close collaboration between the Academies of Sciences of the CPR and the MPR could lead to sound methods of investigation and conservation.

The wild camel has almost as shadowy an existence as the wild horse. Its habitat is said to be further to the east in the long belt of desert country along the frontier. Diagrams and descriptions of the wild camel are to be seen in the local museums of the southern or gobi provinces, and local patriots make oral claims for the animals' existence in their area. But the same is true of the wild horse, and it seems clear that the wild horse does not survive at any place other than the one described by Dr. Kaszab. Occasionally in a museum there is a stuffed specimen of a wild camel, but it is invariably somewhat old.

The continued existence of the wild ass is better documented. Up to the end of the 20's it could be seen in fairly large numbers both north and south of the Altay range, in the north-western region of lakes and desert, and also in the far north-east. Now it is rare and is found only in the trans-Altay deserts as far west as the area of the Przewalski horse and as far east as the frontier districts of the South Gobi province. In the museums of the southern, gobi provinces it is possible to see occasional photographs of the wild ass and not just diagrams and drawings as with the wild horse and wild camel. Stuffed specimens can be seen here and there. Hunting of the wild ass has been completely forbidden since at least 1962.

With the argali and ibex, the picture begins to improve considerably. The argali was declared a rare and protected animal in 1953 and the ibex in 1963 (but this may be a misprint for 1953 in the Mongolian source). Both have increased since then, but the ibex seems to have done better than the argali. Both are to be found along the length of the Mongolian Altay and Gobi Altay ranges, the numbers of argali being largest in Khovd, Gobi Altay and Bayankhongor provinces. Both animals can also be found, though not in large numbers, in the mountains west of Lake Khövsgöl and in the south-western Khangay mountains. Between 1961 and 1964 some experiments with the processing of ibex hides for leather were said to be successful, and ibex hunting to obtain skins for this purpose has been permitted from time to time by special decrees of the Great People's Khural. Otherwise the hunting of argali and ibex is prohibited, except to rare foreign visitors who pay high prices for their sport. In 1965 an American from Texas bagged three or four argali. In October 1965 I saw both argali and ibex at about 6,000 ft. in the Gurvan Saykhan Uul (Three Beauties Mountains) west of Dalandzadgad in the South Gobi province. There were flocks and herds in the nearby valleys, but the 
argali and ibex behaved as though the area belonged to them and not to man. It seems reasonable to suppose that they are even more secure in the higher parts of the Altay ranges which stretch some thousand kilometres westwards and culminate in Bayan Ölgiy province in the area where Carruthers had such splendid sport before the first world war, as described at the beginning of the second volume of his Unknown Mongolia.

The MPR claims three antelopes. The largest is the saiga, of which there used to be two subspecies, one living in the trans-Altay gobi and one in the gobi areas north of the Altay which separate the Altay from the Khangay ranges. The trans-Altay one is now said to be extinct; the other exists in small numbers but is slowly increasing. The saiga was declared a rare and protected animal in 1953. An experimental project for herding saiga in farms is said to have been launched in their native gobi. The horns of the saiga are traditionally prized for their use in certain medical preparations.

The black-tailed antelope (Mongolian "khar sü̈llt dzeer", Russian "dzheyran") is a gazelle living in the empty trans-Altay gobi areas along the frontier with China, but not now extending further east than Sayn Shand on the trans-Mongolian railway; a few are also found in the region north of the Altay where the saiga survives. The black-tail is not very numerous and is hunted during a short autumn season by individual hunters (i.e. not in an organised way on a commercial scale).

The most numerous antelope is the white antelope (Mongolian "tsagaan dzeer", Russian "dzeren"), which is one of the principal targets of organised, commercial hunting. It used to be plentiful all over the open steppes of the centre, east, south and south-east, but now there are almost none in Central and Khentey provinces, and it has become rare in East Gobi, Middle Gobi, South Gobi, Övörkhangay and Bayankhongor provinces. Its main area now is in the south-east, in Sükhbaatar province (Dariganga) and in the southern steppes of the Eastern province. The state procured an average of 726.5 tons of white antelope meat annually between 1951 and 1961. Another source expresses this figure as 50,000 white antelope procured annually. At the same time there was much private hunting of white antelope, amounting in Sükhbaatar province alone to about 4,500 head a year. A figure given for average annual total killings of antelope of all types is 70,000 . Some of the meat was exported, and probably still is, presumably to the Soviet Union, which would not be difficult in the very severe frosts of the Mongolian winter. In the past the white antelope has suffered much from hunters on motorcycles and in jeeps, but pursuit by these means is now forbidden. The open season for white antelope lasts from autumn to early spring, but it is being suggested that this is too long, that the animals lose much weight and are not worth taking after the turn of the year.

The roe deer, which follows the white antelope in importance as a source of meat and shares the same open season, frequents the woodlands of the forest steppe zone, chiefly in the Khentey mountains, in the Orkhon valley (Khangay mountains), in the mountains of Khövsgöl and also in the Khalkh river valley and the foothills of the Khingan mountains in 
the far eastern tip of the MPR. It is rare in the Mongolian Altay. A few are still to be found in Sükhbaatar province.

There is almost no information obtainable about the bear and the wild boar, although both have the same long open season as the white antelope and roe deer. There are stuffed specimens of both on display in the local museums of the northern (mountain and woodland) provinces. The implication is that neither is rare. The tourist organisation is ready to arrange hunting trips for both. A bear skin in which to wrap one's legs is the greatest luxury for winter travelling in Mongolia, a luxury which was always offered to me and always accepted. The only published figure relating to bears suggests that between one and two hundred are killed annually. There is a second and very rare bear in the MPR, the small gobi bear, which was mentioned in Dr. Kaszab's articles in the December 1966 issue of ORYX. It is fully protected, but its existence is precarious, perhaps as much so as that of the wild horse and wild camel.

The Siberian deer is now fully protected and appears to be multiplying successfully. It inhabits the forests of the Khangay, Khentey, Khingan and Mongolian Altay mountains and also the mountains of Khövsgöl. A few are to be found in the Gobi Altay mountains and the Selenge river basin. The antlers of the Siberian deer (and also those of the roe deer), collected when in velvet (or, as the Mongolian language expresses it, when full of blood), are esteemed both at home and abroad for their value in certain medical preparations, and it appears that various other parts of the deer also have an export value in the field of oriental medicine. There are plenty of Siberian deer in the forests of Bogdo Uul, the mountain massif overlooking Ulan Bator from the south, but few people climb up to see them.

There is no detailed information available on the elk, musk deer and reindeer, but all three are fully protected, which seems to imply a "rare" classification. The elk is reported to be multiplying more promisingly than the other two. Reindeer are bred and herded by the Uriankhay inhabitants of the Darkhad depression to the west of Lake Khövsgöl, where the headwaters of the Yenisei river begin.

Of Mongolia's fur-bearing mammals, by far the most important is the marmot, of which there are two races, the Altay marmot and the Siberian marmot, the latter being a little smaller and blonder. Marmots abound in a broad belt right across the north and middle of the country, in the forest steppe and the open steppe, but not in the thicker Siberian taiga of Khövsgöl and Khentey. The state procures a million or so marmot skins a year, and smoked marmot meat plays a part in provincial diets. There seems to be a feeling that procurement targets should be set a little lower in the interests of conservation; the MPR could not afford to let its supply of marmot skins for export dwindle.

The squirrel (a very dark brown in summer time) occupies second place in fur procurement, but its numbers and the quantities procured have declined sharply since the end of the 50's. Squirrels are now rare in the Altay mountains and not numerous elsewhere, i.e., in the Khentey and Khangay mountains and the mountains of Khövsgöl. They seem to 
thrive in the game reserve near Ulan Bator where, of course, they are safe from hunters.

After the squirrel come the red fox and the tartar fox or corsak. These animals, except in the higher mountains and desert areas, are common throughout the MPR. The state procures some 40,000 red fox and 30,000 tartar fox skins annually. The wolf is also encountered nearly everywhere, 4,000 skins are procured annually by the state.

The other fur-bearing animals which contribute to the MPR's trade are the wild cat, which lives in the steppes, the hare, which is everywhere except in the northern taiga, and the Mustelidae. In the 20's some 300 to 500 sable skins used to be collected annually, but since 1953 the sable has been a rare and protected animal, living in the taiga country of Khövsgöl and Khentey. A few are said to live in the game reserve on Bogdo Uul by Ulan Bator. The polecat seems to be the most important mustelid from the point of view of fur procurement. It is found everywhere except in the highest mountains, the emptiest deserts and the thickest taiga. Next comes the stoat or ermine, which inhabits the wooded parts of all the mountain ranges. A small quantity of skins is also collected from the Siberian weasel in the north and centre of the country and the Altay weasel in the south.

There is little detailed information available about the badger, lynx and snow leopard, all of which can be hunted in season. The lynx and snow leopard, being predators, could be becoming rare without receiving much sympathy. Forty or fifty snow leopards are said to be killed annually. The figures given for lynx killings vary from 500 to upwards of 2,000 a year, and for badgers from 800 to well over 2,000 .

There are beaver in the Bulgan river in Khovd province, and there is a black beaver said to be imported from Voronezh in the Soviet Union on the Yeröö river about mid-way between Ulan Bator and the Soviet border to the north. Timber cutting apparently disturbs them on both the Bulgan and the Yeröo. They are classified as rare and protected animals. The otter, raccoon-dog and marten are also protected animals and are described as rare, but there is no detailed information about them.

An animal which does not figure in the game laws but appears in some statistics of skin procurements is the chipmunk, of which six to seven thousand are collected annually.

\section{BIRDS}

The Mongolian Academy of Sciences claims that there are some 300 species of bird in the MPR of which about 30 are either edible or produce edible eggs; but the Mongols do not make much use of them. The MPR lies on the migratory routes of a large number of geese, duck and cranes. There is good shooting by the rivers and lakes of the northern foreststeppe zone in the autumn and spring; but the birds are sometimes so little used to danger from man that they fly up sluggishly and present too easy targets. The following is a list of the indigenous game birds of the MPR:

Great Bustard-scattered widely over the steppes and along the open river valleys.

Grey partridge (called the Daurian partridge, presumably because it is a 
variety from trans-Baikalia)-very widely distributed except in gobi areas and some of the eastern steppe areas.

Hazel hen-in the coniferous forests of the Khentey, Khangay, Mongolian Altay and Great Khingan mountains and the mountains of Khövsgöl.

Black grouse - in the mountains of Khövsgöl, the basins of the Tes and Selenge rivers, the forests of Selenge and Khentey provinces and along the Khalkh river in the far eastern tip of the country.

Capercaillie-in the Khangay and Khentey mountains, the mountains of Kbövsgöl, and the Selenge valley.

Willow ptarmigan-in the Mongolian Altay, Khangay and Khentey mountains and the mountains of Khövsgöl.

Rock ptarmigan - as for the willow ptarmigan, but rarer and not in the Khentey mountains.

Pallas's sand grouse-in gobi and semi-gobi areas.

Chukar partridge - in the Mongolian Altay, Gobi Altay, outlying outcrops of these ranges, and the south west of the Khangay mountains. Over 200,000 of these game birds are reported to be procured annually by the state. Much of this meat is probably exported.

Several rare birds are identified and protected by the game laws (see opposite), but the only prohibited game birds are the golden pheasant, the snow partridge and wild swan. The larger birds of prey, from huge condor-like birds in the northern mountains to the eagles which can be seen here and there throughout the country, can be shot freely, being (like wolves) regarded as enemies of the herds. The several buzzard-like and harrier-like birds of prey, are protected, as are also the owls, because they prey on the millions of small rodents which swarm over the pastures and ruin them.

\section{FISH}

The rivers of north-central Mongolia flow to the Arctic Ocean via the Yenisei; those of north-eastern and eastern Mongolia to the Pacific via the Amur. The great lakes in the west have no outlets to the sea. According to the Academy of Sciences there are about 60 species of fish in the MPR, of which 30 are worth fishing.

The foreign visitor will normally encounter only the main river fish of the Arctic and Pacific systems, viz, taymen (related to the huchen of the Danube) lenok, pike and sometimes perhaps grayling. Taymen and lenok both belong to the Salmonidae, the taymen growing very big, well over a metre in length and up to $30 \mathrm{kgs}$ or more in weight, while the lenok reaches perhaps $60 \mathrm{cms}$ and three kgs. Fishing is slowly becoming a popular sport, with many Russian and east European technical assistance experts showing the way. Everyone uses spinning tackle, which for taymen has to be heavy. The River Tuul near Ulan Bator and the nearer points of the Kerulen now tend to be overfished, but further afield there are rivers full of excellent fish, many of which have never seen a fisherman. From November to April the rivers are covered with a metre or two of ice, and anyone fishing for food bores holes in the ice over the deep pools where the rivers do not freeze right down to their beds. 
The MPR has a small organised fishing industry in three places: at Buyr Lake on the eastern border (in the Pacific ocean system), at Ögiy Lake on the Khögshin Orkhön river north of Kharkhorin, the old capital of the great Khans, and at the lakes in the Darkhad depression in the northern mountains west of Lake Khövsgöl, which form the headwaters of the Yenisei (the last two places being in the Arctic system). Their annual catches over a recent ten-year period were: Buyr Lake, 340 to 600 tons; Ögiy Lake, 80 to 120 tons, and Darkhad Lakes, 150 to 170 tons. Some of the fish is exported and some consumed in Mongolia, but the Mongols have little taste for fish.

At the Darkhad Lakes the catch consists mostly of the Yenisei whitefish which is related to the famous omul of Lake Baikal. It seems that the present close season in September is bad and may need to be moved back into August. Apart from the whitefish the catch consists of taymen, lenok and grayling. At Ögiy Lake the catch is mostly roach, followed in numbers by perch and then pike; there is also crucian carp. In winter burbot are caught through holes in the ice. At Buyr Lake the catch is more varied, the most important being the carp, followed by the goldfish. Others are Hemibarbus labeo, Erythroculter erythropterus, and E. mongolicus, also the sheat-fish, or catfish, pike and taymen. In the western lakes and inland rivers there are two varieties of Diptychus, but they are not fished commercially.

Only one fish is mentioned in the game laws, the Siberian sturgeon, fishing of which is prohibited. Its whereabouts are not stated, but it presumably frequents some parts of the Arctic river system.

\section{THE GAME LAWS}

A game law was introduced in the MPR in 1934, but its detailed provisions are not available. In 1944 it was replaced by a new law based on the principles that game and fish are state property and that hunting should serve social and economic purposes. Hunting of the Przewalski horse, saiga, cow elk, hind of the Siberian deer, sable, marten, beaver, otter, musk-rat (which had appeared in Selenge province from Siberia in 1943), golden pheasant and swan was forbidden except by special permission of the Council of Ministers. Generous open seasons, running usually from August or September to March, were established for wild ass, argali, ibex, stag of the Siberian deer, bull elk, roe deer (does), musk deer, wild boar, white antelope (does), black-tailed antelope or gazelle (does), fox, tartar fox, squirrel, hare, wild cat, marmot, polecat, weasel, ermine, wolverine, and wildfowl in general. The open season for marmot and polecat in fact covered the whole year, but the hunting of marmots could be forbidden by provincial administrations if outbreaks of plague occurred (the fleas carried by marmots used to be important vectors of the plague bacillus). The law specifically stated that buck of the white antelope, black-tailed antelope (gazelle) and roe deer could be hunted at all seasons. Hunting of wolves, snow leopards, lynx, badgers (classified as predators) and predatory birds was declared to be free at all times. The law briefly forbade certain forms of traps and indiscriminate steppe and forest burning, and also prohibited mass round-ups of white antelope "except 
for defined, socially useful purposes". The old holy mountain, Bogd-Uul, overlooking Ulan Bator from the south, was declared a game reserve, by which an ancient tradition of the Mongols was happily preserved. The normal penalty for infringement of the law was a fine of 100 tugriks (today $£ 1=11.15$ tugriks at the official rate of exchange), but the criminal code could be invoked against persistent offenders.

The drafters of the 1944 law appear to have been concerned to ensure controlled exploitation of game reserves as much as to conserve them. It can be assumed that the achievement of controlled exploitation was, at best, uneven for the reasons given at the beginning of this article. A change in the official attitude seems to have occurred in 1953, when several of the dwindling species were declared rare and protected animals. Between 1947 and 1951 a large and comprehensive agricultural mission from the Academy of Sciences of the Soviet Union had been at work in the MPR making a fundamental study of Mongolia's resources-herds, pastures, soil, plant and animal life, etc. Some of the results of this mission's work were published in the 50's in the series "Trudy Mongolskoi Komissii" by the Academy of Sciences of the Soviet Union with the joint sponsorship of the Scientific Committee of the MPR (now the Academy of Sciences of the MPR). These publications contain, inter alia, comprehensive scientific classifications of the flora and fauna. It seems probable that the creation by the Mongolian Government in 1953 of the category of rare and protected animals stemmed from the investigations and findings of the agricultural commission.

In 1962 a new game law was issued. By then collectivisation was complete, and the whole countryside and everything going on in it was embraced by an administrative network capable of implementing effectively the communist principle of democratic centralism. Control over hunting must have become much easier. The list of prohibitions in the 1962 law was much longer than that in the 1944 law and gave complete protection to the Przewalski horse, wild camel, wild ass, Siberian deer, reindeer, elk, musk-deer, saiga, argali, ibex, gobi bear, beaver, otter, sable, marten, raccoon-dog, pelican, swan, golden pheasant, snow partridge, all harriers, owls, eagle-owl, woodpeckers and Siberian sturgeon. Open seasons for other animals were redefined and in most cases considerably shortened:

White antelope, roe deer, bear and

wild boar

Black-tailed antelope (gazelle)

Badger

Marmot

Fox, tartar fox (corsak), squirrel, wild

August 1st to March 1st

September 15 th to October 15th

September 1st to hibernation

August 1st to hibernation

cat, wolverine, polecat, marbled pole-

cat, weasel, ermine (stoat), white hare,

tolai hare, snow leopard, lynx, and

other fur-bearing animals

Musk-rat

Geese, duck and other water birds

October 15th to March 1st

February 15th to March 1st

August 1st to May 15th 
Bustard, partridge, hazel hen, black

grouse, sand-grouse, capercaillie,

ptarmigan and other game birds August 15th to May 1st

The law forbade the use of snares, explosives or nets, the poisoning of water holes, the digging out of hibernating marmots, the flooding out of marmots or other useful rodents (except the "dzuram", or small rodents, which ruin the pasture-lands), the smoking out of animals, antelopehunting by motor vehicle or motorcycle, the destruction of young animals (other than wolf cubs) or of nests and eggs, and any wanton or useless killing. Fines for unlawful killing of animals were set at about $£ 90$ for a wild ass, about $£ 70$ for a deer, reindeer or elk, about $£ 45$ for a beaver, otter, sable or marten, and about $£ 30$ for an argali, ibex or antelope (these figures are calculated at the official rate of exchange, but the real value of the fines would be a third or so less).

In the spring of 1966 , after the holding of a national conference of hunters in 1965, the regulations governing shooting and fishing were tightened, although the prohibitions and open seasons of the 1962 game law appeared to remain unaltered. In general all shooting and fishing are now prohibited unless they contribute to the Mongolian economy by producing furs and skins for processing and export, or fish or meat for consumption and export. The cost of fishing and shooting licences for foreigners has been raised sharply, so that their hunting trips also make contribution to the national economy.

Apart from the activities of foreign visitors, which come under the Administration for the Service of Foreign Travellers, those of the Diplomatic Corps, which come under the Bureau for the Service of the Diplomatic Corps, and those of the foreign technical assistance personnel, which come under their own appropriate organisations, hunting is now organised through associations of hunters in the country's 293 collective and 30 state farms. The associations are required to subject applicants to simple tests and to discipline those who evade the law, kill indiscriminately or fail to deliver quotas of skins and meat to the state authorities. Annual, monthly or other periodical licences are issued by the militia, and inspectors are charged with the task of enforcing the law, particularly in the remote areas of the Gobi provinces. In the vast spaces of Mongolia it cannot be easy to prevent abuses even now; but control should become surer as the settled way of life takes stronger hold and spreads its influence outwards from farm and brigade centres, and as the rural population is increasingly involved in more sophisticated collective work in tending the country's traditional herds and new grain fields. On the other hand the steady increase of vehicles in the countryside reduces the areas undisturbed or rarely disturbed by man and his herds with adverse effects on the larger and more vulnerable wild creatures.

The Administration for the Service of Foreign Travellers (abbreviated in Mongol as Juulchin) has well organised itineraries for foreign tourists to rest houses in the Orkhon valley near Kharkhorin and in the foothills of the Khentey mountains near Ulan Bator, and to encampments of Mongolian tents (Mongolian "ger", Russian "yurt") in the South Gobi 
and Övörkhangay provinces. The cost is high by standards of western tourism-about 14 guineas per day per head. There is plenty of bird and animal life on and near the fairly well-worn tracks to and from these places and in the woods and hills round Ulan Bator, especially in the Bogdo Uul game reserve. But the rarer wild life of the MPR could hardly be seen by visitors on short trips. Distances are very great and it takes several days and much organisation to make an expedition to the remoter areas. Even a good fishing trip needs two or three days. However, for anyone who could afford the luxury of an individually organised shooting trip, probably costing a few hundred pounds, the experience would be unforgettable. Others will have to wait until the tourist itineraries are slowly extended. Most will have to be content to enjoy the wild life vicariously through this article.

\title{
Scientific Names of Mammals Birds and Fish Mentioned in the Text
}

\section{MAMMALS}

\author{
following Ellerman and Morrison-Scott (1951)
}

Vulpes vulpes

$V$. corsac

Nyctereutes procyonoides

Ursus arctos lasiotus

$U$. arctos pruinosus

Martes foina

M. zibellina

Gulo gulo

Mustela erminea

M. eversmanni

$M$. sibirica

M. altaica

Vormela peregusna

Meles meles

Lutra lutra

Felis manul

F. $\operatorname{lynx}$

Panthera uncia

Equus przewalskii

E. hemionus

Camelus bactrianus

Sus scrofa

Moschus moschiferus

Cervus elaphus

Rangifer tarandus

Capreolus capreolus pygargus

Alces alces

Procapra gutturosa

Gazella subgutturosa
Red fox

Tartar fox

Raccoon-dog

Brown bear

Gobi bear

Beech marten

Sable

Wolverine

Stoat or ermine

Polecat

Siberian weasel

Altai weasel

Marbled polecat

Badger

Otter

Pallas's cat

Lynx

Snow leopard

Przewalski horse

Wild ass

Wild camel

Wild boar

Musk deer

Siberian deer

Reindeer

Roe deer

Elk

White antelope

Black-tailed antelope 
Saiga tatarica

Capra ibex sibirica

Ovis ammon

Lepus capensis tolai

L. timidus

Sciurus vulgaris

Marmota bobac

Castor fiber

Ondatra zibethica

\section{BIRDS}

Otis tarda

Tetrastes bonasia

Lyrurus tetrix

Lagopus lagopus

L. mutus

Perdix perdix

Syrrhaptes paradoxus

Tetrao parvirostris

Alectoris chukar

Tetraogallus altaicus

Circus spp.

Bubo bubo

Cygnus cygnus

Pelecanus crispus

Chrysolophus pictus

\section{FISH}

Hucho taimen

Brachymystax lenok

Esox reicherti

Thymallus thymallus

Coregonus sp.

Rutilus rutilus

Perca fuviatilis

Lota lota

Carassius carassius

C. auratus gibelio

Cyprinus carpio

Hemibarbus labeo

Erythroculter erythropterus

E. mongolicus

Silurus glanis

Acipenser baeri
Saiga

Ibex

Argali-wild sheep

Tolai hare

White or varying hare

Red squirrel

Marmot

Beaver

Muskrat

Great Bustard

Hazel hen

Black grouse

Willow ptarmigan

Rock ptarmigan

Grey partridge

Pallas's sand-grouse

Black-billed capercaillie

Chukar partridge (kakelik)

Altai snowcock or snow partridge

Harriers

Eagle-owl

Whooper swan

Pelican

Golden pheasant

Taymen

Lenok

Pike

Grayling

Yenisei whitefish

Roach

Perch

Burbot

Crucian carp

Goldfish

Carp

The identification of some of the animals described only by their Mongolian vernacular names in Mongolian texts has given rise to some difficulty. Existing Mongolian dictionaries give inadequate definitions of many of these names, and existing Mongolian-Russian dictionaries are not exact. However, by using the dictionaries and the Great Soviet 


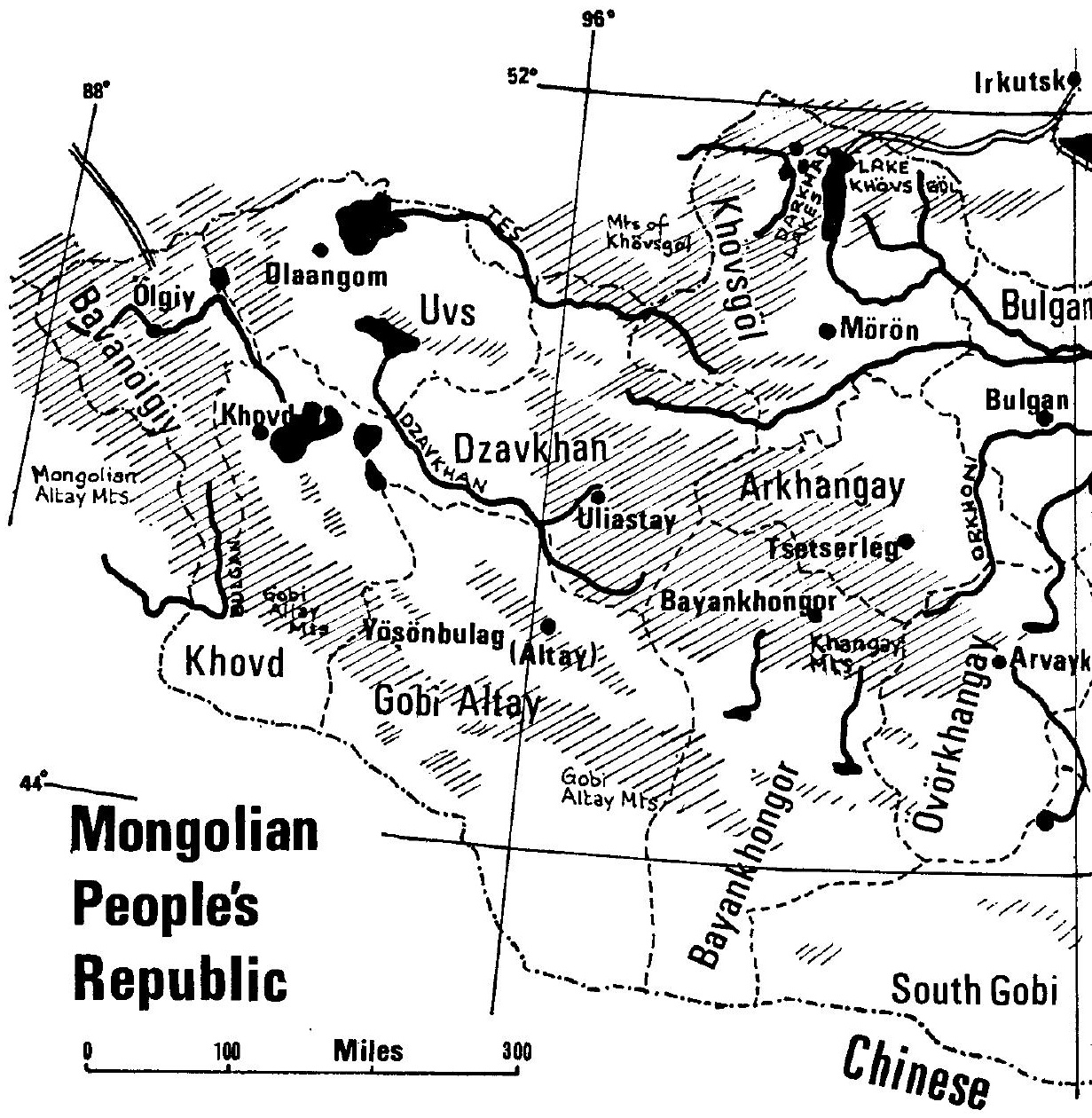




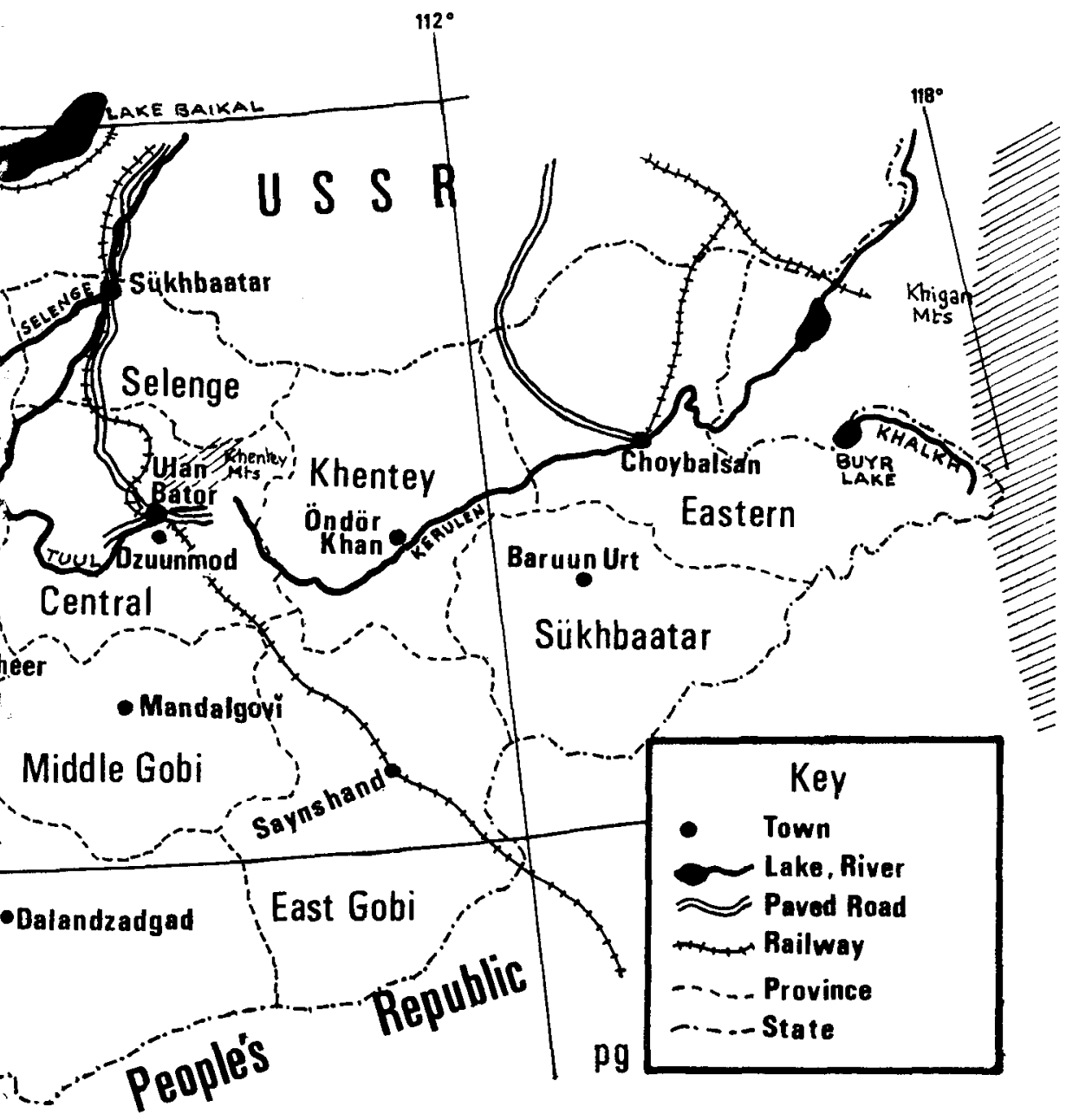


Encyclopedia it has been possible to arrive at confident identifications and so to find correct English names. With the aid of A. G. Bannikov's Opredelitel Mlekopitayushchikh Mongolskoi Narodnoi Respubliki (1953) No. 51 in the series "Trudy Mongolskoi Komissii", published in Moscow jointly by the Academy of Sciences of the USSR and the Scientific Committee of the MPR, it has been possible to establish the scientific names of the animals. It emerges that all mammals listed by Bannikov, with the exception of the wolf and a few insectivores, Chiroptera (bats) and small rodents, are now included in the provisions of the game laws.

The writer is very grateful to the editor of ORXX for her help in obtaining advice on the identification of fish and mammals from Dr. E. Trewavas and Dr. G. B. Corbet of the British Museum (Natural History) and from the Hon. Ivor Montagu.

\section{ORIGINAL SOURCES}

O. SHAGDARSÜREN. Mongol ornï agnuurïn ündsen an amǐtad, Ulan Bator, 1966, under the auspices of the Biological Institute of the Academy of Sciences of the MPR.

YA. DASH AND SH. GONGOR. An agnuurïn tovch medegdekhüün, Ulan Bator, 1965, published under the auspices of the Ministry of State Procurement and Trade of the MPR.

O. NAMNANDORJ. An Amìtad-ulsïn ünet bayalag mön, in Ediyn Dzasgiyn Asuudal, 1967, No. 1, page 29.

A wall poster explaining and illustrating the 1962 game law, published by the Ministry of Agriculture of the MPR in 1965.

S. S. DEMIDOV, editor. Konstitutsiya i osnovniye zakonodatelniye akti Mongolskoi Narodnoi Respubliki, Moscow, 1952 (for the text of the 1944 law).

\section{Cyprus Protects the Mouflon}

The photograph opposite shows the document signed by the Cyprus Minister of Agriculture and Natural Resources, Mr. George Tombazos, and the Chairman of the Survival Service Commission of IUCN, Peter Scott, in which the Cyprus Government accepts ultimate responsibility for a rare animal in its territory, the Cyprian mouflon, or wild sheep. The Cyprus Government was one of nine governments asked by the SSC to accept such responsibility, and the first to accept.

In a letter accompanying the document, the Director-General of the Ministry of Agriculture, says that "the Cyprus Government spares no efforts in taking all the necessary legal and other measures for the protection, preservation and multiplication of the Cyprian mouflon". Its habitat in the mountainous north-west of the island has been declared a Game Reserve Area; no hunting is allowed, and game guards enforce the law and have cut poaching to a minimum. 